\title{
A paddock survey of on-farm plantain use
}

\author{
Mike B. DODD ${ }^{1 *}$, Ray A. MOSS ${ }^{2}$ and Ina J.B. PINXTERHUIS ${ }^{3}$ \\ ${ }^{1}$ AgResearch Ltd, Grasslands Research Centre, Private Bag 11008, Palmerston North 4442, New Zealand \\ ${ }^{2}$ AgResearch Ltd, Canterbury Agriculture and Science Centre, Lincoln Research Centre, Private Bag 4749, \\ Lincoln 7674, New Zealand \\ ${ }^{3}$ DairyNZ Ltd, Canterbury Agriculture and Science Centre, Gerald Street, Lincoln 7608, New Zealand \\ *Corresponding author: mike.dodd@agresearch.co.nz
}

\begin{abstract}
The use of narrow-leaved plantain (Plantago lanceolata) in pasture sowing mixtures has recently increased following research demonstrating the value of the 'Tonic' cultivar in reducing cattle urinary $\mathrm{N}$ concentration, with likely benefits for reducing $\mathrm{N}$ leaching from pasture systems. The purpose of this study was to document the ways in which farmers are using plantain, investigate the factors that enhance successful establishment and persistence, and to test a method of visual estimation of plantain content in paddocks. This information will support verification of animal intake, given that there is evidence that a critical level of plantain is required in the diet to achieve significant effects on $\mathrm{N}$ cycling. In grass-based pastures, plantain content declined with age since sowing and few paddocks had more than $20 \%$ of their available dry matter as plantain after three years. A systematic visual assessment of plantain cover correlated well with a formal visual dry matter assessment and could be used to establish when plantain content at a paddock scale is $>20-30 \%$. Plantain content tended to be highest when sown without grass, when established by direct drilling and on clay soils, but optimal sowing rates have yet to be determined.
\end{abstract}

Keywords: BOTANAL, dry matter, plant populations, visual assessment

\section{Introduction}

New Zealand-bred cultivars of narrow-leaved plantain (Plantago lanceolata L., also known as ribgrass) have been available since 1996 (Stewart et al. 2014). In the last decade, new research has demonstrated the value of some genotypes for the management of nitrate leaching from pastoral systems. Evidence shows consistent reductions in urinary $\mathrm{N}$ concentration from cattle grazing diets containing plantain cv. 'Tonic' (Box et al. 2016; Bryant et al. 2017; Dodd et al. 2018). These results have demonstrated the potential of plantain to contribute to reductions in nitrate leaching via a lower urine patch $\mathrm{N}$ loading (Li et al. 2012), a key environmental issue for intensive grazing systems (Clark et al. 2007).

Central to the effectiveness of plantain in reducing nitrate loss is ensuring that there is sufficient plantain in an animal's diet during periods of high nitrate leaching risk - typically autumn (Shepherd et al. 2011). No clear range has been found from research published to date as to the level necessary, although $30-40 \%$ has been suggested, based on observations showing no effect at levels $<20 \%$ (Bryant et al. 2017; Minneé et al. 2017) but significant effects at levels $>40 \%$ (Box et al. 2017; Minneé et al. 2017; Dodd et al. 2018). The implications of this tentative threshold are that farmers choosing to incorporate plantain in mixed swards will need management guidelines that enable them to maintain this level, and tools to verify that paddocks contain this level.

The objectives of this study were: (a) to assess the on-farm success of establishment and persistence of plantain in mixed swards and explore the management factors influencing success; and (b) to test a visual method for estimating plantain content in mixed swards that could be used for auditing, when farmers want the expected reduction in nitrate leaching to be considered within local and/or national water quality regulatory frameworks.

\section{Materials and Methods Study sites}

In autumn 2018 we surveyed 59 paddocks on 21 dairy and dry-stock farms across New Zealand, in the Waikato, Bay of Plenty, Wairarapa, Rangitikei, Canterbury and Otago regions. The paddocks covered a range of pasture types, including grass-based mixes, clover-based mixes and herb mixes; grass-based mixes were most prevalent (Table 1, details in Appendix 1). Paddocks were also selected to ensure variation in:

Table $1 \quad$ Breakdown of pasture types and farm systems included in the study.

\begin{tabular}{lccc}
\hline Farm Type & Dairy & Sheep/Deer & Cattle $^{\star}$ \\
\hline Number of farms & 9 & 6 & 6 \\
Grass-clover-plantain mixes & 31 & 4 & 14 \\
Clover-plantain mixes & 1 & 8 & 1 \\
\hline
\end{tabular}

${ }^{*}$ incl. dairy support 
(a) time since sowing; (b) sowing rate; and (c) sowing method. Additional data on soil type, fertiliser inputs, grazing management and weed control, were provided by the farmers, but the soil type data were only able to be categorised into a few groups for analysis (four, based on broad texture descriptors).

\section{Paddock measurements}

In-paddock measurements of plantain content were made during April and May of 2018 using two visual estimation methods and plant population counts. The North Island and South Island paddocks were assessed by separate operators. The assessments were made as close in time as possible to planned grazings, to capture the data relevant to animal consumption. This approach resulted in a wide variation in cover at the time of sampling $(1800-4700 \mathrm{kgDM} / \mathrm{ha}$ as estimated by a rising plate meter (Farmtracker: Farmworks Ltd, Fielding) using the standard calibration method, i.e. average compressed pasture height $\times 140+500$; DairyNZ 2019). Details of the measurements are:

1. Visual cover score.

(A) FIELD. Thirty $0.2 \mathrm{~m}^{2}$ quadrat frames, spaced 5-10 paces apart, along a randomly located transect within each paddock, were visually rated for plantain cover, by a vertical projection of the plantain canopy, on a $0-10$ scale. Each unit on the scale covered a range in estimated cover, i.e. $0=$ $0-4 \%, 1=5-14 \%, 2=15-24 \%$ cover, etc. and 10 $=95-100 \%$, is a set of cover classes. The mean paddock score was calculated and multiplied by 10 to give a whole paddock value for the visual $\%$ plantain cover;

(B) PHOTOGRAPHY. A subsample of six frames in each paddock was photographed using a mobile phone camera. Using GIMP2 image processing software (www.gimp.org), the photos were cropped to the frame boundary and the plantain was traced manually on a digital tablet. The areas identified as plantain were shaded and a pixel count recorded. The cover of plantain was calculated as the percentage of pixels shaded.

2. BOTANAL score. This technique is detailed in the report of Tothill et al. (1992). The same 30 frames used for visual scoring were each visually rated for the top three ranking species contributing to the available dry matter in each frame (bearing in mind known differences in the DM content of key species such as plantain, ryegrass, white clover, and assuming typical grazing residual heights for the system). At the paddock scale, the estimate of plantain percentage of available DM was calculated by the equation:

$\% A D M($ Plantain $)=[($ Number of frames with plantain as first ranking species $\times 70)+($ number

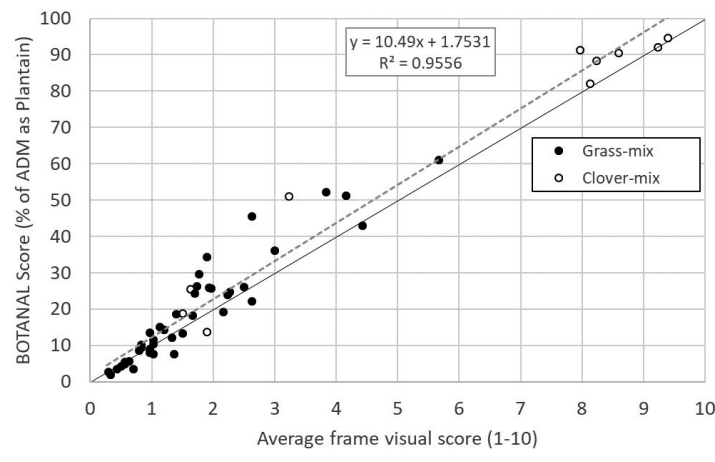

Figure 1 Comparison of paddock BOTANAL score (\% of available DM as plantain) and mean paddock cover score of plantain, for 59 paddocks. Linear fit (dashed) and 10:1 reference line (solid) are shown.

of frames with plantain as second ranking species $\times 21)+$ (number of frames with plantain as third ranking species $\times 9)] / 30$;

3. Plant population. The same 30 frames were each counted for plant numbers, the number scaled up to plants $/ \mathrm{m}^{2}$ (frame count $\times 5$ ) and a mean value calculated for the paddock (35 North Island paddocks only).

\section{Statistical analyses}

The field visual cover and plant population data at the paddock level were analysed by linear regression against the BOTANAL scores to test their utility for estimating plantain content. In addition, the type of visual cover estimates of the subsampled frames (field and photo) were analysed by linear regression to test the accuracy of both visual methods for estimating plantain cover at the plot scale. The field visual cover data at the paddock level for grass-based pastures only were also analysed by linear regression against pasture age and sowing rate, and by unbalanced ANOVA including the factors of sowing season, sowing method and soil type in single-factor analyses (there were insufficient data to analyse interactions) to determine whether these factors influenced the medium-term outcome in terms of plantain content in mixed swards.

\section{Results}

\section{Estimation method}

The relationship between the plantain proportion of DM in each paddock (as assessed by BOTANAL) and the average paddock canopy cover (as assessed by the average field visual score) is shown in Figure 1. The linear fit is strong, with an $\mathrm{R}^{2}$ of $>0.95$. The offset of the linear fit from the reference line (10:1) is approx. $3-6 \%$, i.e. the average field visual cover score tends to underestimate the BOTANAL score. This underestimation appears to be more marked for those 


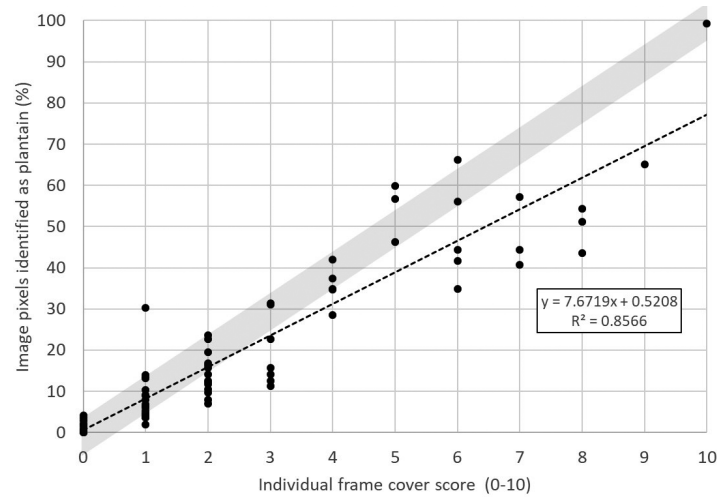

Figure 2 Linear regression of percent cover of plantain as determined by manual photograph tracing versus visual assessment in the field, for 75 individual frames in 18 paddocks. Linear fit (dashed) and 10:1 reference band (shaded) are shown.

paddocks with a mid-range of plantain, i.e. a 5-15\% underestimate for paddocks with $30-60 \%$ plantain content. By contrast, the relationship between the BOTANAL content score and the plant population estimate was very poor, with an $\mathrm{R}^{2}$ of the linear regression of 0.23 (based on 35 North Island paddocks only, data not shown).

The relationship between the visual score in the field $(0-10)$ and the proportion of the photo image identified as plantain, was moderately good (Figure 2) as the linear fit had an $\mathrm{R}^{2}$ of $>0.85$. However, the slope of the linear equation was much less than would be expected if the field visual assessment were accurately estimating the vertically projected cover. The reference line is presented as a 10:1 band in Figure 2 as the technique allows for a $\pm 5 \%$ variation in cover around the visual score. This approach shows that the field visual technique consistently over estimates the vertically projected cover at the plot scale when plantain content is high $(>60 \%)$.

\section{Plantain content}

For both visual and BOTANAL assessment methods, plantain content was generally higher in clover-based mixtures, as indicated by the open circles in Figure 1. The mean paddock visual score for clover mixes was 6.0 compared with 1.5 for grass mixes. However, the clover mixes typically had higher original sowing rates (Figure 3), and there was a significant positive regression relationship between sowing rate and percent plantain cover across the whole data set (slope $5.2, \mathrm{P}<0.01$ ). Based on visual score, there was a wide range in plantain cover in paddocks where the sowing rate had been greater than $4 \mathrm{~kg} / \mathrm{ha}$. For example, several paddocks sown at rates of 6-8 $\mathrm{kg}$ did not have substantially higher plantain cover than those with

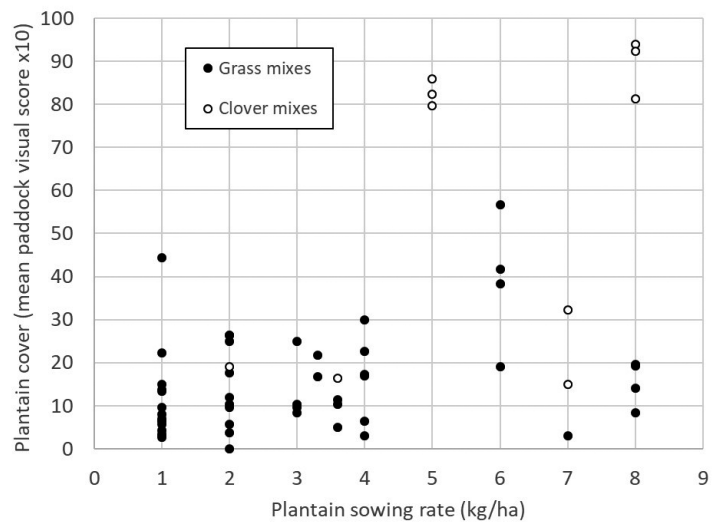

Figure 3 Plantain cover (visual field score) versus original plantain sowing rate for 49 grass-based mixes and 10 clover-based mix paddocks.

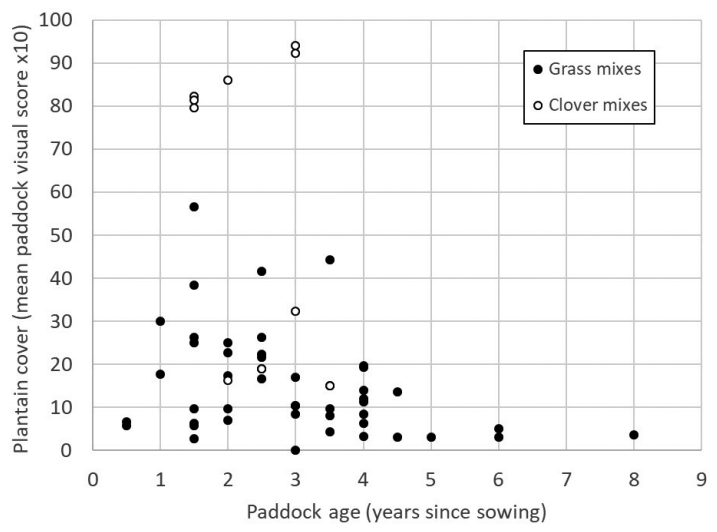

Figure 4 Plantain cover versus paddock age since sowing for 49 grass-based mixes and 10 clover-based mix paddocks.

sown at lower rates (Figure 3). Only one paddock sown at less than $4 \mathrm{~kg} / \mathrm{ha}$ had a plantain cover greater than $30 \%$.

With respect to time since sowing, the regression relationship with plantain cover was significant and negative (slope $-5.0, \mathrm{P}<0.05$ ). Of 36 paddocks older than two years (i.e. sown before 2016), only three clover mixes and two grass mixes had more than $30 \%$ plantain cover (Figure 4). Of 20 paddocks older than three years (i.e. sown before 2015), only one grass mix had more than $20 \%$ plantain cover (Figure 4). While both of the grass mix paddocks were direct drilled, the 3.5 -year old pasture was sown at $1 \mathrm{~kg} / \mathrm{ha}$ of plantain in a $20 \mathrm{~kg} / \mathrm{ha}$ new grass mix and grazed with sheep, the 2.5 -year old pasture was under-sown at $6 \mathrm{~kg} / \mathrm{ha}$ of plantain and grazed by dairy cows.

The ANOVA analysis of grass-based pasture management factors showed a significant effect of both sowing method and soil type on visual plantain cover, such that cover was greatest on direct drilled paddocks 
and on clay soils (Table 2). However, there was no significant difference in plantain cover between sowing seasons.

\section{Discussion}

The field visual cover technique was broadly consistent with the BOTANAL technique for estimating the percentage of available dry matter at the wholepaddock scale. Visual estimation, using a limited set of cover scores, was more rapid than the BOTANAL technique but similar techniques using cover range classification have been reported to over-estimate the cover of rare species and are best when considering dominant species (Floyd \& Anderson 1987). The cover scoring technique is based on a vertical projection so it is potentially amenable to automation via image analysis, which would mitigate observer biases. Thus, a visual measurement of cover is a potentially useful rapid assessment tool for verifying plantain content in a paddock, particularly if the objective is not so much to obtain a precise assessment, but determine if the paddock meets a certain threshold of content. However, there was a tendency for the field visual method to overestimate actual cover at high levels of cover relative to careful manual tracing of photographs at the individual frame scale. On the other hand, the data in Figure 1 suggest that visual scoring led to overestimation of \%ADM as measured by BOTANAL. These two results suggest that the visual field assessors were not entirely focussed on apparent cover but may be subconsciously accounting for the visible plantain in the top layer of the canopy. Experience and training will be important in ensuring the consistency and repeatability of visual estimates among observers (Symstad et al. 2008). The implication of this finding for automated assessment is that a linear relationship based on apparent cover from an image will actually underestimate plantain content, in terms of the proportion of available dry matter.

In grass-based pastures, plantain content was lower in older pastures and few paddocks sown more than three years previously had more than $20 \%$ of their available dry matter as plantain. While technically a perennial species, plantain has been described as a long-lived biennial in the context of mixed pastures (Stewart 1996). A technique for establishing the age of individual plants has recently been demonstrated and could be applied in New Zealand pastures to verify this (Roeder et al. 2019). One factor limiting the longevity of plantain in mixed pastures may be grazing management. Optimal grazing management guidelines for pure plantain swards have been developed (Powell et al. 2007; Lee et al. 2015). However, these are unlikely to be applied in mixed pastures; the farmers in this survey reported that the pastures were typically managed as a standard grass/clover pasture.

Our analysis of various factors underlying greater plantain content indicated that clover-based mixtures performed better than grass-based pastures, although this result was probably confounded by higher sowing rates for clover pasture and the lower number of clover pastures studied.

For grass-based pastures, the data could not generate a clearly defined plantain sowing rate that could be reliably linked to a plantain content of $\geq 30 \%$, and recent experience with sowing rate experiments and farm monitoring supports this lack of reliability (Bryant et al. 2019). The study also suggested that direct drilling was the most successful method of establishment, as reported by Glassey et al. (2013) and Bryant et al. (2019), and that clay soils maintained higher plantain content. In a semi-controlled study of this nature, where persistence appears to be quite paddock-specific, these results must be considered provisional.

\section{Conclusions/Practical implications/ Relevance}

Visual estimation in the field appears to give a good rapid assessment of plantain content, particularly when mixed pastures have $>30 \%$ plantain

Table 2 Mean effects of sowing method, sowing season and soil type on plantain cover for 49 grass-based paddocks of varying age and sowing rate.

\begin{tabular}{|c|c|c|c|c|c|}
\hline Sowing method & Plantain cover* (\%) & Sowing season & Plantain cover* (\%) & Soil type & Plantain cover* (\%) \\
\hline Broadcast & 8.4 & Spring & 26.6 & Clayey & 52.8 \\
\hline Cultivated & 18.9 & Summer & 9.6 & Silty & 22.3 \\
\hline \multirow[t]{2}{*}{ Direct drilled } & 34.3 & Autumn & 20.9 & Sandy & 10.2 \\
\hline & & & & Stony & 15.8 \\
\hline Max SED & 10.2 & & 13.0 & & 10.5 \\
\hline $\mathrm{P}$-value & $<0.05$ & & 0.37 & & $<0.01$ \\
\hline
\end{tabular}

\footnotetext{
* Based on visual cover scoring method
} 
contribution to available DM. Plantain content appears to decline below this level after two years and may suffer from competition in grass-based mixtures. Plantain is behaving as a short-term perennial in these situations, and cost-effective means of maintaining content above $30 \%$ beyond three years are needed. Such measures may include regular under-sowing or changes in grazing management that do not compromise pasture quality. Plantain content tended to be higher when established by direct drilling and on clay soils but, at present, optimal sowing rates remain elusive.

\section{ACKNOWLEDGEMENTS}

This research was part of the Forages for Reduced Nitrate Leaching programme, with principal funding from the New Zealand Ministry of Business, Innovation and Employment. The programme is a partnership between DairyNZ Ltd, AgResearch, Plant \& Food Research, Lincoln University, The Foundation for Arable Research and Manaaki Whenua - Landcare Research. The cooperation of the farmers and their staff is gratefully recognised. Several industry professionals assisted in making contact with the farmers: Duncan Thomas (H\&T Agronomics); Scott Cameron, Adam Duker, Wilma Foster (Dairy NZ); Allister Moorhead, Jason Waterman (PGGW Seeds).

\section{REFERENCES}

Box LA, Edwards GR, Bryant RH. 2016. Milk production and urinary nitrogen excretion of dairy cows grazing perennial ryegrass-white clover and pure plantain pastures. Proceedings of the New Zealand Society of Animal Production 76: 18-21.

Box LA, Edwards GR, Bryant RH. 2017. Milk production and urinary nitrogen excretion of dairy cows grazing plantain in early and late lactation. New Zealand Journal of Agricultural Research 60(4): 470-482.

Bryant RH, Dodd MB, Moorhead AJE, Edwards P, Pinxterhuis IJB. 2019. Effectiveness of strategies used to establish plantain into existing pastures. Journal of New Zealand Grasslands 81: 131-138.

Bryant RH, Miller ME, Greenwood SL, Edwards GR. 2017. Milk yield and nitrogen excretion of dairy cows grazing binary and multispecies pastures. Grass and Forage Science 72(4): 806-817.

Clark DA, Caradus JR, Monaghan RM, Sharp P, Thorrold BS. 2007. Issues and options for future dairy farming in New Zealand. New Zealand Journal of Agricultural Research 50(2): 203-221.

DairyNZ 2019. https://www.dairynz.co.nz/feed/ pasture-management/assessing-and-allocatingpasture/pasture-assessment/. Accessed 14 May 2019.

Dodd MB, Dalley D, Wims, C, Elliott D, Griffin A 2018. A comparison of temperate pasture species mixtures selected to increase dairy cow production and reduce urinary nitrogen excretion New Zealand Journal of Agricultural Research Vol 62 issue 4 pp504-527 which is actually 2019 but it was first published online in 2018. https://doi.org/10.1080/00 288233.2018.1518246

Floyd DA, Anderson JE. 1987. A comparison of three methods for estimating plant cover. Journal of Ecology 75(1): 221-228.

Glassey CB, Clark CEF, Roach CG, Lee JM. 2013. Herbicide application and direct drilling improves establishment and yield of chicory and plantain. Grass and Forage Science 68: 178-185.

Lee JM, Hemmingson NR, Minneé EMK, Clark CEF. 2015. Management strategies for chicory (Cichorium intybus) and plantain (Plantago lanceolata): impact on dry matter yield, nutritive characteristics and plant density. Crop and Pasture Science 66(2): 168-183.

Li FY, Betteridge K, Cichota R, Hoogendoorn CJ, Jolly BH. 2012. Effects of nitrogen load variation in animal urination events on nitrogen leaching from grazed pasture. Agriculture, Ecosystems and Environment 159: 81-89.

Minneé EMK, Waghorn GC, Lee JM, Clark CEF. 2017. Including chicory or plantain in a perennial ryegrass/white clover-based diet of dairy cattle in late lactation: Feed intake, milk production and rumen digestion. Animal Feed Science and Technology 227: 52-61.

Powell AM, Kemp PD, Jaya KD, Osborne MA. 2007. Establishment, growth and development of plantain and chicory under grazing. Proceedings of the New Zealand Grassland Association 69: 41-45.

Roeder A, Schweingruber FH, Fischer M, Roscher C. 2019. Increasing plant diversity of experimental grasslands alters the age and growth of Plantago lanceolata from younger and faster to older and slower. Oikos https://doi.org/10.1111/oik.05739

Shepherd M, Phillips P, Snow VO. 2011. The challenge of late summer urine patches in the Waikato Region. In: Currie LD, Christensen CL, Eds. Adding to the knowledge base for the nutrient manager. Occasional Report No. 24. Fertilizer and Lime Research Centre, Massey University, Palmerston North, New Zealand. http://flrc.massey.ac.nz/publications.html.

Stewart A. 1996. Plantain (Plantago lanceolata) - a potential pasture species. Proceedings of the New Zealand Grassland Association 58: 77-86.

Stewart A, Kerr G, Lissaman W, and Rowarth J. 2014. Pasture and Forage Plants for New Zealand. Grassland Research and Practice Series No. 8. New Zealand Grassland Association, Dunedin.

Symstad AJ, Wienk CL, Thorstenson AD. 2008. Precision, repeatability, and efficiency of two canopycover estimate methods in Northern Great Plains 
vegetation. Rangeland Ecology and Management 61: 419-429.

Tothill JC, Hargreaves JNG, Jones RM, McDonald CK. 1992. BOTANAL A comprehensive sampling and computing procedure for estimating pasture yield and composition. 1. Field Sampling Tropical Agronomy Technical Memorandum No. 78. CSIRO Division of Tropical Crops and Pastures, St. Lucia, Brisbane, QLD, Australia.
Appendix 1 Survey paddock details by farm type, location and paddock type

\begin{tabular}{|c|c|c|c|}
\hline Farm ID & Farm type & Region & $\begin{array}{l}\text { Paddock type and } \\
\text { number of paddocks }\end{array}$ \\
\hline 1 & Dairy & N Waikato & G-C-P (4) \\
\hline 2 & Dairy & N Waikato & G-C-P (3) \\
\hline 3 & Dairy & N Waikato & G-C-P (3), C-P (1) \\
\hline 4 & Cattle & Bay of Plenty & G-C-P (4) \\
\hline 5 & Sheep & Rangitikei & C-P (1) \\
\hline 6 & Dairy & N Wairarapa & G-C-P (3) \\
\hline 7 & Dairy & N Wairarapa & G-C-P (3) \\
\hline 8 & Cattle & N Wairarapa & G-C-P (4) \\
\hline 9 & Dairy & Wairarapa & G-C-P (2) \\
\hline 10 & Dairy & Wairarapa & G-C-P (7) \\
\hline 11 & Sheep & Wairarapa & G-C-P (1), C-P (1) \\
\hline 12 & Sheep & N Canterbury & G-C-P (1) \\
\hline 13 & Sheep & N Canterbury & C-P (3) \\
\hline 14 & Cattle & N Canterbury & G-C-P (2) \\
\hline 15 & Sheep & N Canterbury & G-C-P (2), C-P (1) \\
\hline 16 & Cattle & N Canterbury & G-C-P (2) \\
\hline 17 & Cattle & N Canterbury & G-C-P (2) \\
\hline 18 & Dairy & S Canterbury & G-C-P (3) \\
\hline 19 & Dairy & Otago & G-C-P (3) \\
\hline 20 & Sheep/Deer & Otago & C-P (2) \\
\hline 21 & Cattle & Otago & C-P (1) \\
\hline
\end{tabular}

${ }^{*}$ G-C-P, Grass-Clover-Plantain (Grass-based); C-P, Clover-Plantain (Clover-based) 